\section{Re: En mann i 70-årene med infeksjon og alvorlig syre-base-forstyrrelse}

Det finnes studier som har vist en assosiasjon mellom laktacidose og tiaminmangel, både ved sepsis og ved enkelte andre tilstander $(1,2)$. Fant dere normalt nivå av tiamin hos denne pasienten?

\author{
Morten Juul Sundnes
}

morten.sundnes@me.com

Morten Juul Sundnes (f. 1973) er lege i spesialisering ved St. Olavs hospital. Ingen oppgitte interessekonflikter

\section{Litteratur \\ 1. Moskowitz A, Graver A, Giberson T et al. The relationship between lactate and thiamine levels in patients with diabetic ketoacidosis. J Crit Care 2014; 29: e5-8. 2. Andersen LW, Mackenhauer J, Roberts JC et al. Etiology and therapeutic approach to elevated lactate levels. Mayo Clin Proc 2013; 88: 1127-40.}

\section{E. Helskog og medarbeidere svarer:}

Her svarer forfatterne/forfatteren på et innlegg som er publisert på nett og $i$ Tidsskriftet nr. 9/2014.

Vi finner det underlig at Nina E. Jensen velger å se bort fra denne kasuistikkens ubestridelige faktum: at pasienten vi beskriver hadde en rekke psykotiske symptomer. Søkelyset på at elektrokonvulsiv terapi (ECT) kan ha en effekt på kronisk utmattelsessyndrom/myalgisk encefalopati (CFS/ME), og at dette betyr at pasienten led av $\mathrm{ME}$, er en grov diagnostisk forenkling. Det er dessuten ikke tilstrekkelig evidens for å bevise kausalitet, og heller ikke nok evidens til å konkludere med at elektrokonvulsiv terapi har effekt på pasienter med kronisk utmattelsessyndrom/myalgisk encefalopati.

Vi vil understreke at denne artikkelen ikke er noen anbefaling om å benytte elektrokonvulsiv terapi til pasienter med kronisk utmattelsessyndrom/myalgisk encefalopati. Det får gruppestudier med strenge vitenskapelige krav vurdere. Vår hensikt er å beskrive et pasientforløp hvor vi mener at pasienten ikke var tilstrekkelig utredet, spesielt med tanke på å utelukke psykiatriske diagnoser.

Jensen skriver at pasienter med kronisk utmattelsessyndrom/ myalgisk encefalopati kan oppleve lydhallusinasjoner, men vi lurer på om hun da mener hallusinasjoner med vrangforestillinger? Mange mennesker har hallusinasjoner av forskjellige modaliteter av ulike årsaker, uten at disse er realitetsbristende. Referansene som oppgis er også noe underlige, særlig artikkelen fra Young ME sufferers Trust. Denne artikkelen fremstår svært lite uavhengig, er ikke fagvurdert, er publisert av en interesseorganisasjon for barn og unge med kronisk utmattelsessyndrom/myalgisk encefalopati, og omhandler i all hovedsak barn, så vidt vi kan forstå. Det er vanskelig å se hvordan denne referansen, og referansen til en 13 år gammel bok, kan brukes for å legitimere at de beskrevne lydhallusinasjonene best lar seg forklare av kronisk utmattelsessyndrom/ myalgisk encefalopati. Ingen av disse referansene egner seg således til å trekke slutninger om diagnostisk validitet generelt.

Med mindre Jensen tar utgangspunkt i at kronisk utmattelsessyndrom/myalgisk encefalopati også er en psykoselidelse? Det kommer ikke klart frem, men vi tror ikke dette er hva Jensen forsøker å si.

At en diagnose består av kliniske observerbare symptomer, betyr ikke nødvendigvis at det er en enkel sak å gi pasienter riktig diagnose. I hvert fall ikke når symptomene er generelle og kan passe innunder mange forskjellige diagnoser. Jensen refererer til Canadian Consensus Criteria for CFS/ME $(1,2)$. Om man for eksempel tar for seg kriterium 4 om kognitive/nevrologiske kriterier, nevnes ti problemområder, deriblant konsentrasjonsproblemer. Dette er et symptom som er felles for så å si alle psykiatriske diagnoser. Det samme gjelder for mange av de andre kriteriene.

Som nevnt i vår artikkel, er det også verdt å merke seg at Helse- direktoratet ikke tar endelig stilling til hvilket av flere sett med diagnosekriterier som er i bruk, som bør være gjeldende (3).

Det er ingen tvil om at det må ryddes opp i utredning og behandling av kronisk utmattelsessyndrom/myalgisk encefalopati, og nok en gang kommer man ikke utenom at det må tas psykiatriske anamneser for å utelukke psykiske lidelser. Det er svært uheldig dersom pasienter som har en psykisk lidelse, blir behandlet som pasienter med kronisk utmattelsessyndrom/myalgisk encefalopati.

\section{Espen Helskog}

espenhauk@hotmail.com

Kristin Bjartveit

Espen Helskog (f. 1977) er psykolog ved Nedre Romerike DPS, Akershus universitetssykehus.

Ingen oppgitte interessekonflikter

Kristin Bjartveit (f. 1957) er spesialist i psykiatri og overlege ved Psykiatrisk avdeling Arendal, Sørlandet sykehus. Hun var tidligere ved Avdeling akuttpsykiatri, Akershus universitetssykehus.

Ingen oppgitte interessekonflikter.

\section{Litteratur \\ 1. Carruthers BM, Jain AK, De Meirleir KL et al. Myalgic encephalomyalitis/chronic fatigue syndrome: Clinical working definition, diagnostic and treatment proto- cols. J Chronic Fatigue Syndr 2003; 11: 7-115. \\ 2. Carruthers BM, van de Sande MI, De Meirleir KL et al. Myalgic encephalomyeli- tis: International Consensus Criteria. J Intern Med 2011; 270: 327-38. \\ 3. Helsedirektoratet. Nasjonal veileder. Pasienter med CFS/ME: Utredning, dia- gnostikk, behandling, rehabilitering, pleie og omsorg. Oslo: Helsedirektoratet, 2013. \\ Re: Medisinske funn i en tverrfaglig geriatrisk fallpoliklinikk}

Oslo universitetssykehus rapporterer om sine første erfaringer med en fallpoliklinikk (1) og finner ikke helt uventet at multimorbiditet og polyfarmasi er hyppig assosiert med falltendens. $13 \%$ av de henviste hadde hatt tidligere frakturer. Opprettelsen av fallpoliklinikken er et betimelig og velkomment tiltak.

Finske undersøkelser har vist at forekomsten av skader i forbindelse med fall er økende selv om den aldersspesifikke insidensen synes å være avtakende (2). Heldigvis fører fall også hos eldre oftest til relativt små skader, men om lag $7-8 \%$ av de fallulykkene som krever legetilsyn, fører til innleggelse i sykehus. Mer enn $70 \%$ av disse innleggelsene er foranlediget av frakturer (3). Interessant er det at insidenskurven for fall hos eldre er svært lik insidenskurven for hoftefrakturer. Frakturer er også en selvstendig risikofaktor både for nye fall og fremtidig redusert helse (3).

Uventet var det derfor at verken osteoporoseutredning eller frakturforebyggende behandling ble nevnt $\mathrm{i}$ artikkelen eller $\mathrm{i}$ den ledsagende lederen (4). En fallpoliklinikk må forventes å ha et vidt repertoar gitt både de mange årsakene til fall og de behandlingsmulighetene man har. Selv om ulike tiltak kan redusere falltilbøyeligheten hos en eldre person, viser flere undersøkelser at «fallerne» til tross for tiltakene vil fortsette å falle (5-7), om enn forhåpentligvis ikke så hyppig som tidligere. Man må derfor også vurdere hvilke andre skadeforebyggende tiltak som skal iverksettes. Frakturforebygging må her sies å være et sentralt element. Heldigvis finnes for dette formålet gode diagnostiske og behandlingsmessige tiltak (8) som jeg håper fallpoliklinikken vil ta med seg i sitt videre virke.

\section{Johan Halse}

johalse@online.no

Johan Halse (f. 1944) er daglig leder av Osteoporoseklinikken.

Oppgitte interessekonflikter: Forfatter har hatt konsulentoppdrag for MSD Norge AS og Lilly Norge AS. Han har mottatt honorar for foredrag og møtedeltakelse fra Amgen AB Norge. 